\title{
Mengelola Kinerja Tim Engineering: Dari Iklim Kecerdasan Emosional hingga Team Efficacy
}

\author{
Nelson Silitonga ${ }^{1}$ \\ Muhammad Johan ${ }^{2}$ \\ Masduki Asbari ${ }^{3}$ \\ Dhaniel Hutagalung ${ }^{4}$ \\ Dewiana Novitasari ${ }^{5}$ \\ ${ }^{1}$ Sekolah Tinggi Ilmu Ekonomi Insan Pembangunan \\ Email: nelsonsilitonga76ueu@gmail.com \\ ${ }^{2}$ Sekolah Tinggi Ilmu Ekonomi Insan Pembangunan \\ Email: johanm29@yahoo.com \\ ${ }^{3}$ STMIK Insan Pembangunan \\ Email: kangmasduki.ssi@gmail.com \\ ${ }^{4}$ Sekolah Tinggi Ilmu Ekonomi Insan Pembangunan \\ Email: dhanielhutagalung@gmail.com \\ ${ }^{5}$ Sekolah Tinggi Ilmu Ekonomi Insan Pembangunan \\ Email: dhewiediosa@yahoo.co.id
}

\begin{abstract}
Abstrak
Berdasarkan Social Cognitive Theory (SCT), penelitian ini mendalilkan karakteristik tim dan faktor lingkungan sebagai pendorong utama kinerja tim (team performance). Dalam model yang diusulkan dari studi ini, kinerja tim dipengaruhi secara positif dan signifikan oleh dua prediktor (yaitu, team efficacy dan iklim kecerdasan emosional). Demikian juga, perencanaan tim kerja berpengaruh secara positif dan signifikan terhadap kinerja tim. Data dikumpulkan dari 157 kuesioner yang dikembalikan dari sampel yang diambil secara random sampling dari karyawan engineering sebuah perusahaan manufaktur di Indonesia. Data dianalisis menggunakan metode SEM dengan software SmartPLS 3.0. Hasil penelitian ini menunjukkan bahwa team efficacy dan iklim kecerdasan emosional berpengaruh positif dan signifikan terhadap perencanaan tim kerja dan kinerja tim. Demikian juga perencanaan tim kerja berpengaruh secara positif dan signifikan terhadap kinerja tim. Selain itu, pengujian empiris penelitian ini, dengan menyelidiki para teknisi engineering yang bekerja di industri manufaktur Indonesia, melengkapi penerapan teori kognitif sosial dalam memahami kinerja tim. Terakhir, implikasi manajerial tentang kinerja tim dan open problem di masa depan dibahas pada akhir laporan penelitian.
\end{abstract}

Kata kunci: Iklim kecerdasan emosional, kinerja tim, perencanaan tim kerja, team efficacy.

\section{PENDAHULUAN}

Sebuah tim dalam organisasi mewakili sekelompok individu pegawai yang menganggap diri mereka sebagai kumpulan sosial yang dapat diidentifikasi dalam suatu organisasi (Richter et al., 2005). Kerjasama dalam tim telah mendapat banyak perhatian dari psikolog sosial dan organisasi, karena hal itu membawa manfaat penting bagi karyawan dan organisasinya, seperti menyediakan cara yang efektif untuk mengumpulkan ide-ide kreatif, meningkatkan komunikasi antarpribadi, meningkatkan semangat tim, memfasilitasi perencanaan tim, dan meningkatkan kinerja tim (misal, O'Leary \& Mortensen (2010)). Literatur sebelumnya mengungkapkan bahwa kinerja tim tetap menjadi masalah abadi dan penting bagi banyak praktisi dan akademisi (Levy et al., 2003). Sebuah teori kunci yang telah menghasilkan minat yang cukup besar sebagai alasan untuk menjelaskan kinerja tim adalah teori kognitif sosial/social cognitive theory (SCT) dari Bandura (Prusia \& Kinicki, 1996). SCT Bandura's (1986) adalah teori yang memberikan wawasan tentang perilaku masyarakat dan kinerja mereka. Menurut SCT, karyawan memiliki system organisasi yang memungkinkan mereka untuk melakukan tindakan pengendalian atas pikiran, perasaan, dan tindakan mereka (Tsai et al., 2009). Sistem ini menyediakan mekanisme referensi dan seperangkat sub-fungsi untuk memahami, mengatur, dan mengevaluasi perilaku, yang dihasilkan dari interaksi antara sistem dan sumber pengaruh lingkungan (Tsai et al., 2009). SCT telah banyak digunakan dalam berbagai disiplin ilmu dan pengaturan praktis dan telah menerima dukungan empiris dari penelitian sebelumnya tentang masalah tim yang terus 
berkembang. Misalnya, efikasi tim, komponen penting dari SCT, telah ditemukan terkait dengan masalah anggota tim seperti kesulitan tujuan yang ditetapkan tim, kepuasan kerja, kesejahteraan psikologis, perilaku kewarganegaraan organisasi/organizational citizenship behavior (OCB) (Joe \& Lin, 2008) dan kinerja tim (Gully et al., 2002).

Hasil penelitian sebelumnya menunjukkan bahwa hubungan antara efikasi tim dan kinerja tim dimediasi oleh berbagai variabel mediasi seperti pemberdayaan kepemimpinan (Chen et al., 2010), perilaku belajar tim (van Emmerik et al., 2011), dan tujuan tim (Chen et al., 2010). Memperluas temuan sebelumnya, studi ini lebih jauh mengeksplorasi team efficacy yang mempengaruhi kinerja tim berdasarkan SCT. Faktor mediasi penting untuk hubungan kinerja tim-team efficacy adalah perencanaan tim yang mewakili taktik pengaturan diri tim yang diadopsi oleh anggota tim untuk mengejar tujuan tim (misalnya, Mehta et al. (2009)).

Perencanaan tim kerja didefinisikan sebagai aktivitas bekerja sama yang mengharuskan tim untuk menyusun tindakan yang dapat digunakan untuk mencapai tujuan yang telah dipilih (Mehta et al., 2009). Penelitian sebelumnya telah menyarankan bahwa perencanaan tim kerja (yaitu, swa-regulasi) secara langsung mempengaruhi kinerja (Gully et al., 2002; Mehta et al., 2009), dan tim dengan tingkat efikasi yang berbeda dapat merespons secara berbeda dengan berbagai taktik pengaturan diri untuk memandu aktivitas kerja sama dari waktu ke waktu (Mehta et al., 2009). Perencanaan tim kerja telah diakui sebagai mediator meta-kognitif penting untuk peningkatan kinerja tim. Sebagai contoh, Holton (2001) menemukan bahwa kepercayaan tim berhubungan signifikan dalam perencanaan berkualitas tinggi. DeShon dan Gillespie (2005) menunjukkan "rencana aksi" sebagai cara yang efisien untuk mencapai tujuan organisasi dan pembuktian kinerja, sehingga menyarankan peran mediasi potensial dari perencanaan tim. Berry (2011) menyarankan bahwa kerja tim dengan komunikasi yang efisien dapat menghindari kurangnya perencanaan tim kerja dan pada akhirnya mencapai performa tim yang prima.

Penelitian ini menilai bagaimana perencanaan tim kerja, sebagai taktik pengaturan diri utama, memediasi hubungan antara team efficacy, iklim kecerdasan emosional dan kinerja tim. Perencanaan tim kerja telah diakui sebagai pendekatan regulasi penting dan proses berbasis tim untuk meningkatkan kinerja tim. Perencanaan adalah keterampilan meta-kognitif penting yang berpengaruh terhadap kinerja organisasi (Ford et al., 1998). Tim menggunakan perencanaan sebagai taktik untuk mengoordinasikan berbagai aktivitas rumit, sehingga meningkatkan kinerja mereka (Weldon et al., 1991). Terlepas dari bukti bahwa perencanaan bersama adalah taktik pengaturan diri yang vital, sedikit perhatian telah diberikan untuk mengevaluasi peran perantara dalam pembentukan kinerja bersama berdasarkan SCT, yang dibahas dalam penelitian ini.

Penelitian ini berbeda dengan penelitian sebelumnya dalam tiga hal penting. Pertama, penelitian sebelumnya yang meneliti kinerja tim berdasarkan SCT sebagian besar menekankan pengaruh karakteristik tim (misalnya, team-efficacy) pada kinerja tim, tetapi mengabaikan variabel lingkungan (misalnya, iklim kecerdasan emosional) pada kinerja. Dengan memasukkan kedua factor kinerja, baik karakteristik tim maupun faktor lingkungan, studi ini dapat memperoleh pemahaman yang mendalam secara mendalam tentang kinerja tim. Kedua, studi ini mengevaluasi perencanaan tim yang belum teruji sebagai mediator pembentukan kinerja tim berbasis SCT dengan antseden team-efficacy dan iklim kecerdasan emosional. Model ini masih relevan untuk diteliti dan diuji, lebih-lebih di industri manufaktur. Studi ini juga mencoba melengkapi literature sebelumnya dengan mensurvei hubungan antara team-efficacy sebagai factor individual dan iklim kecerdasan emosional sebagai factor lingkungan dengan kinerja tim, yang dimediasi oleh perencanaan tim.

\section{KAJIAN PUSTAKA DAN PENGEMBANGAN HIPOTESIS}

Untuk membangun model kinerja tim, studi ini mengambil dari postulat kunci dan temuan dalam social cognitive theory (SCT) (Bandura, 2001). SCT Bandura's (1986) adalah teori yang diterima secara luas yang memberikan alasan kritis mendalam untuk membenarkan bagaimana tim melakukan perilaku tertentu dan mencapai hasil selanjutnya. SCT menjelaskan fungsi tim dalam hal penyebab timbal balik di mana karakteristik tim, faktor lingkungan (yang mengelilingi tim) dan perilakunya beroperasi sebagai penentu interaksi dari perilaku dan hasil tim. Berdasarkan SCT, studi ini mengusulkan model penelitian di mana perencanaan tim kerja dan kinerja tim (yaitu, perilaku dan hasil) secara langsung dipengaruhi oleh karakteristik tim (yaitu, team efficay) dan faktor lingkungan (yaitu, iklim kecerdasan emosional). Sementara itu, kinerja tim juga dipengaruhi oleh perencanaan tim kerja. 
Asumsi dalam model ini dapat dibenarkan tidak hanya dari perspektif teoritis SCT, tetapi juga dari sudut pandang kerja sama praktis. Sebagai contoh, banyak literatur sebelumnya telah menunjukkan bahwa hasil kerjasama yang baik membutuhkan tingkat tertentu dari dalam (misalnya, self-efficacy) dan dari luar (misalnya, organizational climate).

Perencanaan tim sebagai taktik pengaturan diri adalah proses kognitif dan perilaku yang memandu aktivitas tim yang diarahkan pada tujuan dari waktu ke waktu (Kanfer, 1992; Zimmerman, 2001). Untuk berhasil mengejar tujuan tim, penting untuk memiliki team efficacy yang kuat sehingga perencanaan tim dapat dirancang secara efektif dan efisein oleh tim. Memang. Perencanaan tim kerja adalah komponen penting dari meta-kognisi (Brown et al., 1983), yang mengacu pada kesadaran dan kontrol individu atas kognisi mereka (Flavell, 1979). Tim dengan efektivitas yang lebih tinggi menunjukkan keterampilan meta-kognitif yang lebih baik karena mereka memiliki kepercayaan diri untuk merencanakan tugas mereka, mengantisipasi masalah sebelumnya, dan kecepatan dalam menyesuaikannya (Ford et al., 1998), menunjukkan hubungan positif antara team efficacy dan perencanaan tim. Sebaliknya, tim dengan efikasi rendah sering kali ragu-ragu untuk merencanakan aktivitas penting dan melakukannya tepat waktu, akibatnya perencanaan tim yang lemah. Berdasarkan dasar pemikiran dan justifikasi di atas, maka dikembangkan hipotesis sebagai berikut.

\section{H1. Team efficacy berpengaruh positif dan signifikan terhadap perencanaan tim kerja.}

Team efficacy berasal dari individu anggota tim, dan melalui proses pengalaman tugas tim yang saling bergantung dan interaksi sosial yang aktif, self-efficacy anggota bersama-sama menyatu menjadi variabel tingkat tim (Kozlowski \& Klein, 2000). Team efficacy adalah kepercayaan diri (atau keyakinan) tim mengenai peluangnya untuk berhasil menyelesaikan misi tim tertentu (Kreitner \& Kinicki, 2007). Team efficacy memengaruhi apa yang coba dilakukan oleh anggota tim, berapa banyak upaya yang mereka lakukan untuk mengejar tujuan tim, dan ketekunan mereka ketika upaya tim yang gagal mencapai target tim (Bandura, 1997). Studi sebelumnya telah menunjukkan hubungan yang kuat antara team efficacy dan kinerja tim (misalnya, Hakim \& Bono (2001), Knight et al. (2001)). Tim dengan team efficacy yang tinggi diperkirakan akan berhasil mencapai kinerja yang baik dalam berbagai situasi pencapaian (Schenkel dan Garrison, 2009). Akibatnya, team efficacy yang kuat memfasilitasi peningkatan kinerja tim mereka setelah kegagalan, sementara efikasi tim yang lemah menyebabkan kinerja tim menurun (Bandura, 2000). Dengan demikian hipotesis diturunkan seperti di bawah ini.

\section{H2. Team efficacy berpengaruh positif dan signifikan terhadap kinerja tim.}

Kecerdasan emosional diyakini dapat meningkatkan rasa tanggung jawab, pemecahan masalah, pengujian realitas, toleransi stres, kontrol impuls, dan kebahagiaan individu (Olukayode \& Ehigie, 2005). Kondisi ini menumbuhkan suasana dan iklim positif dalam sebuah tim (Olukayode \& Ehigie, 2005). Pengaruh penting kecerdasan emosional pada proses perencanaan dan kegiatan tim telah disebutkan dalam literatur sebelumnya (Robins, 2002). Peneliti menyarankan bahwa iklim kecerdasan emosional berharga untuk tim kerja dan komponen kerja yang sangat diperlukan (Olukayode dan Ehigie, 2005). Tim kerja yang dikelilingi oleh iklim kecerdasan emosional yang tinggi cenderung memiliki kemauan yang kuat untuk terus bekerja sama untuk perencanaan tim mereka. Penelitian sebelumnya tentang iklim kecerdasan emosional menunjukkan bahwa tim dengan iklim kecerdasan emosional yang kurang terdefinisi dengan baik mempengaruhi konflik hubungan dan peningkatan intensitas konflik (Ayoko et al., 2008), menyebabkan perencanaan tim yang lemah. Iklim kecerdasan emosional secara positif mempengaruhi berbagai perencanaan tim kerja, termasuk keterpaduan tim dan proses interaksi tim (Olukayode dan Ehigie, 2005). Singkatnya, iklim kecerdasan emosional memberi tim kesempatan untuk mengurangi konflik, dan meningkatkan kohesi organisasi dengan membuat skenario yang saling berpola bagi anggota untuk mengikuti aktivitas berdasarkan perencanaan tim, menunjukkan hubungan positif antara kecerdasan emosional dan perencanaan bersama. Dengan demikian, hipotesis diajukan seperti di bawah ini.

\section{H3. Iklim kecerdasan emosional berpengaruh positif dan signifikan terhadap perencanaan tim kerja.}

Iklim kecerdasan emosional dianggap sebagai lingkungan kerja di mana orang mampu memantau perasaan dan emosi mereka sendiri dan orang lain, untuk membedakan di antara mereka dan menggunakan informasi ini untuk memandu tindakan, perencanaan, dan pemikiran tim (Salovey dan Mayer, 1990). Iklim kecerdasan emosional mempengaruhi kinerja bersama di tahap awal dan 
selanjutnya melalui mediator (Perlini \& Halverson, 2006). Secara khusus, iklim kecerdasan emosional membantu memecahkan masalah, yang berkontribusi pada kinerja tim (Jordan \& Troth, 2004). Banyak penelitian telah menekankan hubungan antara iklim kecerdasan emosional dan kinerja tim (misalnya, Ayoko et al. (2008), Rhee (2005), van Kleef et al. (2009)) karena iklim kecerdasan emosional yang baik mewakili kemampuan untuk mengekspresikan emosi yang sesuai untuk memfasilitasi peningkatan kinerja (Côté \& Miners, 2006). Iklim kecerdasan emosional yang kuat yang mendorong pemahaman emosional, regulasi, dan pemanfaatan kemungkinan akan membantu menumbuhkan pertukaran sosial yang positif, dukungan atau nasihat sosial (Law et al., 2004), dan untuk meningkatkan kinerja tim (Côté $\&$ Miners, 2006). Dengan kata lain, tim yang dikelilingi oleh iklim kecerdasan emosional tingkat tinggi lebih mahir dalam mengatur emosi berbasis tim mereka dan mengelola emosi orang lain untuk membina hubungan yang lebih positif dan produktif, akibatnya berkontribusi pada kinerja yang lebih baik (Sy et al., 2006). Dengan demikian, hipotesis yang diajukan seperti di bawah ini.

\section{H4. Iklim kecerdasan emosional berpengaruh positif dan signifikan terhadap kinerja tim.}

Perencanaan bersama adalah proses pengaturan mandiri yang penting (Zimmerman, 2001) yang secara positif mempengaruhi hasil kinerja tim (Holton, 2001). DeShon \& Gillespie (2005) mengusulkan "rencana aksi tim" sebagai alat untuk mencapai penguasaan dan orientasi tujuan yang membuktikan kinerja. Dengan demikian menandakan hubungan perencanaan-kinerja. Studi sebelumnya secara empiris menunjukkan hubungan langsung antara perencanaan tim kerja dan kinerja tim (misalnya, Janicik dan Bartel (2003)). Peneliti lain misalnya, Weingart (1992) menemukan pengaruh positif dari perencanaan tim kerja terhadap kinerja kelompok siswa. Demikian pula, Weldon et al. (1991) menyebutkan bahwa perencanaan tim kerja secara positif terkait dengan kinerja tim dalam tugas produksi. Dengan kata lain, tim yang terlibat dalam perencanaan tim yang lebih besar lebih mungkin untuk memperoleh kinerja yang lebih besar dibandingkan dengan tim yang melakukan perencanaan tim yang lebih sedikit (DeShon \& Gillespie, 2005). Konsekuensinya, dikembangkan hipotesis seperti di bawah ini.

\section{H5. Perencanaan tim kerja berpengaruh positif dan signifikan terhadap kinerja tim.}

Menurut Sekaran \& Bougie (2016) kerangka teoritis adalah fondasi yang mendasari seluruh proyek penelitian. Dari kerangka teori tersebut dapat dirumuskan hipotesis yang dapat diuji untuk mengetahui valid tidaknya teori yang dirumuskan. Kemudian selanjutnya akan diukur dengan analisis statistik yang sesuai. Mengacu pada teori dan penelitian sebelumnya, maka penulis membangun model penelitian sebagai berikut:

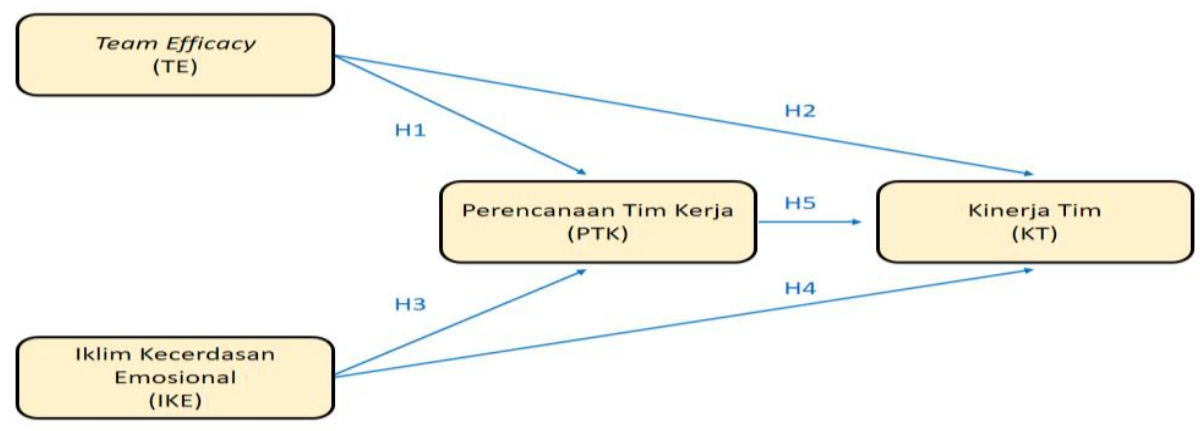

Gambar 1. Model Konseptual Penelitian

\section{METODE PENELITIAN}

\section{Pengumpulan data}

Menurut Creswell \& Creswell (2017), jika tujuan dari penelitian ini adalah untuk mengetahui hubungan pengaruh antar variabel yang diteliti, maka pendekatan kuantitatif adalah yang terbaik. Metode penelitian kuantitatif adalah cocok dalam menguji teori dan hipotesis melalui penggunaan seperangkat alat statistik (Creswell \& Creswell, 2017). Oleh karena itu, penelitian ini menggunakan metode kuantitatif survei untuk menguji hipotesis yang dirumuskan. Oleh karena itu, diadopsi kuesioner digunakan sebagai instrumen untuk mengumpulkan data yang dibutuhkan. 
Populasi penelitian terdiri dari 157 karyawan sebuah industry manufaktur di Jawa Barat. Seperti yang disarankan dan diadopsi oleh penelitian sebelumnya, responden yang sesuai dari penelitian ini adalah para pengatur di perusahaan, mulai kepala regu, hingga manajer puncak, karena mereka memegang posisi kritis dalam organisasi yang memungkinkan mereka mampu memberikan informasi yang dapat dipercaya mengenai lingkungan dasar dan karakteristik organisasi mereka (Hung et al., 2010). Dengan menggunakan simple random sampling, 267 kuesioner dikirim secara online kepada populasi. 157 kuesioner dikembalikan dan valid, yang membentuk tingkat tanggapan $58.8 \%$. Menurut Roscoe (1975) rule of thumb mengemukakan bahwa ukuran sampel adalah lebih dari 30 dan kurang dari 500 sesuai untuk sebagian besar penelitian, oleh karena itu, sampel diperoleh ukuran untuk penelitian ini dianggap sesuai.

\section{Pengukuran dan Skala}

Karena sifat penelitian ini yang melibatkan efek dependen antara konstruk laten dan variabel manifes, model pengukuran reflektif cocok untuk penelitian ini (Hair Jr et al., 2017). Team efficacy diukur dengan menggunakan empat item (TE1-TE4) dari Mosley et al. (2008). Iklim kecerdasan emosional diukur dengan menggunakan empat item (IKE1-IKE4) dari Law et al. (2004)). Perencanaan tim kerja diukur dengan menggunakan empat item (PTK1-PTK4) dari Mehta et al. (2009)) Sedangkan untuk mengukur kinerja tim, empat item (KT1-KT4) yang diadaptasi dari Lin (2010). Semua variabel diukur pada skala tipe Likert lima poin. Tiap item pertanyaan/pernyataan tertutup diberikan lima opsi jawaban, yaitu: sangat setuju (SS) skor 5, setuju (S) skor 4, netral/ raguragu (N) skor 3, tidak setuju (TS) skor 2, dan sangat tidak setuju (STS) skor 1. Metode untuk mengolah data adalah dengan PLS dan menggunakan software SmartPLS versi 3.0 sebagai toolnya. Lebih lengkap untuk daftar item yang digunakan pada penelitian ini bisa dilihat pada Tabel 1. Penelitian pendahuluan terhadap 30 responden dilakukan untuk memastikan keandalan dan validitas pengukuran di atas dalam konteks karyawan manufaktur di Indonesia. Hasil studi percontohan menunjukkan bahwa konsistensi internal konstruk utama berkisar antara 0.79 hingga 0.87 , yang melebihi ambang batas 0.70 seperti yang disarankan oleh (J. F. Hair et al., 2014).

\section{Analisis data}

Teknik statistik paling populer di bawah Structural Equation Model SEM adalah berbasis kovarian pendekatan (CB-SEM) dan teknik kuadrat terkecil parsial berbasis varian (PLS-SEM) (Sarstedt et al., 2014). Namun, PLS-SEM akhir-akhir ini mendapat perhatian yang luas di banyak orang disiplin ilmu seperti pemasaran, manajemen strategis, sistem informasi manajemen, dan cabang keilmuan lainnya (Hair et al., 2012). Kemampuan PLS-SEM untuk menangani permasalahan problematic modelling yang biasa terjadi di lingkungan social ilmu pengetahuan seperti karakteristik data yang tidak biasa (misalnya data non-normal) dan model yang sangat kompleks adalah alasan penting di balik peningkatan penggunaan pendekatan ini. Mengingat keuntungan dari pendekatan ini, penelitian ini menggunakan PLS-SEM untuk menguji secara keseluruhan dari hipotesis yang diajukan. Perangkat lunak SmartPLS 3.0 digunakan untuk mengevaluasi masing-masing outer model dan inner model. Pengujian outer model dilakukan untuk memastikan keandalan dan validitas pengukuran, sedangkan hipotesis yang diperkenalkan diperiksa melalui inner model.

Tabel 1. Daftar Item Penelitian

\begin{tabular}{ll}
\hline Notasi & Item \\
\hline Team & Efficacy (TE) \\
TE1 & Tim saya percaya diri untuk saling membantu guna memenuhi tuntutan kualitas kerja tim. \\
TE2 & Tim saya percaya diri untuk saling membantu guna memperbaiki kesalahan kerja tim. \\
TE3 & Tim saya yakin dalam mengingatkan satu sama lain untuk mengikuti semua aturan keselamatan. \\
TE4 & Tim saya percaya diri dalam bekerja sama untuk menjaga efektivitas kerja tim. \\
& \\
Iklim Kecerdasan Emosional (IKE) \\
Mengenai iklim kecerdasan emosional di tim saya, saya anggota tim merasa bahwa... \\
IKE1 & Kami bisa mengendalikan amarah, sehingga kami bisa menangani kesulitan secara rasional. \\
IKE2 & Kami cukup mampu mengendalikan emosi kami sendiri. \\
IKE3 & Kami selalu bisa tenang dengan cepat saat kami sangat marah. \\
IKE4 & Kami memiliki kendali yang baik atas emosi kami sendiri. \\
\hline
\end{tabular}




\section{Perencanaan Tim Kerja (PTK) \\ PTK1 Tim saya memahami tujuan dari suatu masalah sebelumnya mencoba menjawab. \\ PTK2 Tim saya dengan hati-hati merencanakan tindakannya. \\ PTK3 Tim saya mencari tahu tujuannya dan apa yang perlu dilakukan untuk mencapainya. \\ PTK4 Tim saya mengembangkan rencana untuk solusi dari masalah.}

\section{Kinerja Tim (KT)}

KT1 Kolaborasi tim saya mengurangi redundansi konten pekerjaan

KT2 Kolaborasi tim saya meningkatkan tim efisiensi

KT3 Kolaborasi tim saya mengkoordinasikan upaya tersebut dari semua orang di tim

KT4 Kolaborasi tim saya memfasilitasi inovasi ide baru

\section{HASIL DAN PEMBAHASAN \\ Hasil}

Jumlah total ada 157 karyawan yang turut berpartisipasi. Terbanyak adalah pria $(67.5 \%)$, kemudian wanita (32.5\%). Mereka mempunyai kelompok usia yang berbeda-beda, di bawah 30 tahun (25.5\%), berkisar di antara 30-40 tahun (46.5\%), dan lebih dari 40 tahun (28.0\%). Masa kerja mereka sebagai karyawan juga cukup beragam, sebagian di antaranya di bawah 5 tahun (35.0\%), berkisar di antara 5-10 tahun (49.1\%), dan lebih dari 10 tahun (15.9\%). Tingkat pendidikan mayoritas diploma/sarjana (87.9\%) kemudian SMA/SMK (12.1\%),

Table 2. Deskripsi Sampel

\begin{tabular}{|c|c|c|c|}
\hline \multicolumn{2}{|c|}{ Kriteria } & \multirow{2}{*}{$\begin{array}{c}\text { Jumlah } \\
106\end{array}$} & \multirow{2}{*}{$\frac{\%}{67.5 \%}$} \\
\hline Jenis Kelamin & Laki-laki & & \\
\hline & Wanita & 51 & $32.5 \%$ \\
\hline \multirow[t]{3}{*}{ Usia (per Maret 2021) } & $<30$ tahun & 40 & $25.5 \%$ \\
\hline & $30-40$ tahun & 73 & $46.5 \%$ \\
\hline & $>40$ tahun & 44 & $28.0 \%$ \\
\hline \multirow[t]{3}{*}{ Masa kerja sebagai karyawan } & $<5$ tahun & 55 & $35.0 \%$ \\
\hline & 5-10 tahun & 77 & $49.1 \%$ \\
\hline & $>10$ tahun & 25 & $15.9 \%$ \\
\hline \multirow[t]{2}{*}{ Ijazah tertinggi } & Diploma/Sarjana & 138 & $87.9 \%$ \\
\hline & SMA/SMK & 19 & $12.1 \%$ \\
\hline
\end{tabular}

Tahap pengujian model pengukuran meliputi pengujian validitas konvergen, validitas diskriminan. Sementara untuk menguji reliabilitas konstruk digunakan nilai cronbach's alpha dan composite reliability. Hasil analisis PLS dapat digunakan untuk menguji hipotesis penelitian jika seluruh indikator dalam model PLS telah memenuhi syarat validitas konvergen, validitas deskriminan dan uji reliabilitas.

Uji validitas konvergen dilakukan dengan melihat nilai loading factor masing-masing indikator terhadap konstruknya. Pada sebagian besar referensi, bobot faktor sebesar 0.5 atau lebih dianggap memiliki validasi yang cukup kuat untuk menjelaskan konstruk laten (Chin, 1998; Ghozali, 2014; Hair et al., 2010). Pada penelitian ini batas minimal besarnya loading factor yang diterima adalah 0.5 , dengan syarat nilai AVE setiap konstruk > 0.5 (Ghozali, 2014). Setelah melalui pengolahan SmartPLS 3.0, ada beberapa indikator atau item yang perlu dikeluarkan dari model, yakni: KK4 dan KK6. Selanjutnya, setelah itu, seluruh indikator telah memiliki nilai loading factor di atas 0.5 atau dengan syarat nilai AVE di atas 0.5. Model fit atau valid dari penelitian ini bias dilihat pada Gambar 2. Jadi dengan demikian, validitas konvergen dari model penelitian ini sudah memenuhi syarat. Nilai loadings, cronbach's alpha, composite reliability dan AVE setiap konstruk selengkapnya dapat dilihat Gambar 2 dan Tabel 3. 
Discriminant validity dilakukan untuk memastikan bahwa setiap konsep dari masing-masing variabel laten berbeda dengan variabel laten lainnya. Model mempunyai discriminant validity yang baik jika nilai kuadrat AVE masing-masing konstruk eksogen (nilai pada diagonal) melebihi korelasi antara konstruk tersebut dengan konstruk lainnya (nilai di bawah diagonal) (Ghozali, 2014). Hasil pengujian discriminant validity adalah dengan menggunakan nilai kuadrat AVE, yakni dengan melihat FornellLarcker Criterion Value diperoleh sebagaimana ditunjukkan pada Tabel 4. Hasil uji validitas deskriminan pada tabel 3 di atas menunjukkan bahwa seluruh konstruk telah memiliki nilai akar kuadrat AVE di atas nilai korelasi dengan konstruk laten lainnya (melalui kriteria Fornell-Larcker). Demikian juga nilai cross-loading seluruh item dari suatu indikator lebih besar dari item indikator lainnya sebagaimana disebut pada Tabel 4, sehingga dapat disimpulkan bahwa model telah memenuhi validitas deskriminan (Fornell \& Larcker, 1981). Selanjutnya, evaluasi kolinearitas dilakukan untuk mengetahui apakah ada kolinearitas dalam model. Untuk menemukan collinearity, diperlukan penghitungan VIF dari setiap konstruk. Jika skor VIF lebih tinggi dari 5, maka model tersebut memiliki collinearity (Hair et al., 2014). Sebagaimana ditunjukkan pada Tabel 5, semua skor VIF lebih kecil dari 5, artinya bahwa model ini tidak memiliki masalah collinearity.

Reliabilitas konstruk dapat dinilai dari nilai cronbach's alpha dan composite reliability dari masing-masing konstruk. Nilai composite reliability dan cronbach's alpha yang disarankan adalah lebih dari 0.7 (Ghozali, 2014). Hasil uji reliabilitas pada tabel 2 di atas menunjukkan bahwa seluruh konstruk telah memiliki nilai composite reliability dan cronbach's alpha lebih besar dari 0.7 (> 0.7). Kesimpulannya, seluruh konstruk telah memenuhi reliabilitas yang dipersyaratkan.

Pengujian hipotesis dalam PLS disebut juga sebagai uji inner model. Uji ini meliputi uji signifikansi pengaruh langsung dan tidak langsung serta pengukuran besarnya pengaruh variabel eksogen terhadap variabel endogen. Untuk mengetahui pengaruh team efficacy dan iklim kecerdasan emosional terhadap kinerja tim engineering dengan melalui perencanaan tim kerja sebagai variable mediasi dibutuhkan uji pengaruh langsung dan tidak langsung. Uji pengaruh dilakukan dengan menggunakan uji t-statistik dalam model analisis partial least squared (PLS) dengan menggunakan bantuan software SmartPLS 3.0. Dengan teknik boothstrapping, diperoleh nilai $R$ Square dan nilai uji signifikansi sebagaimana Tabel 6 dan Tabel 7.

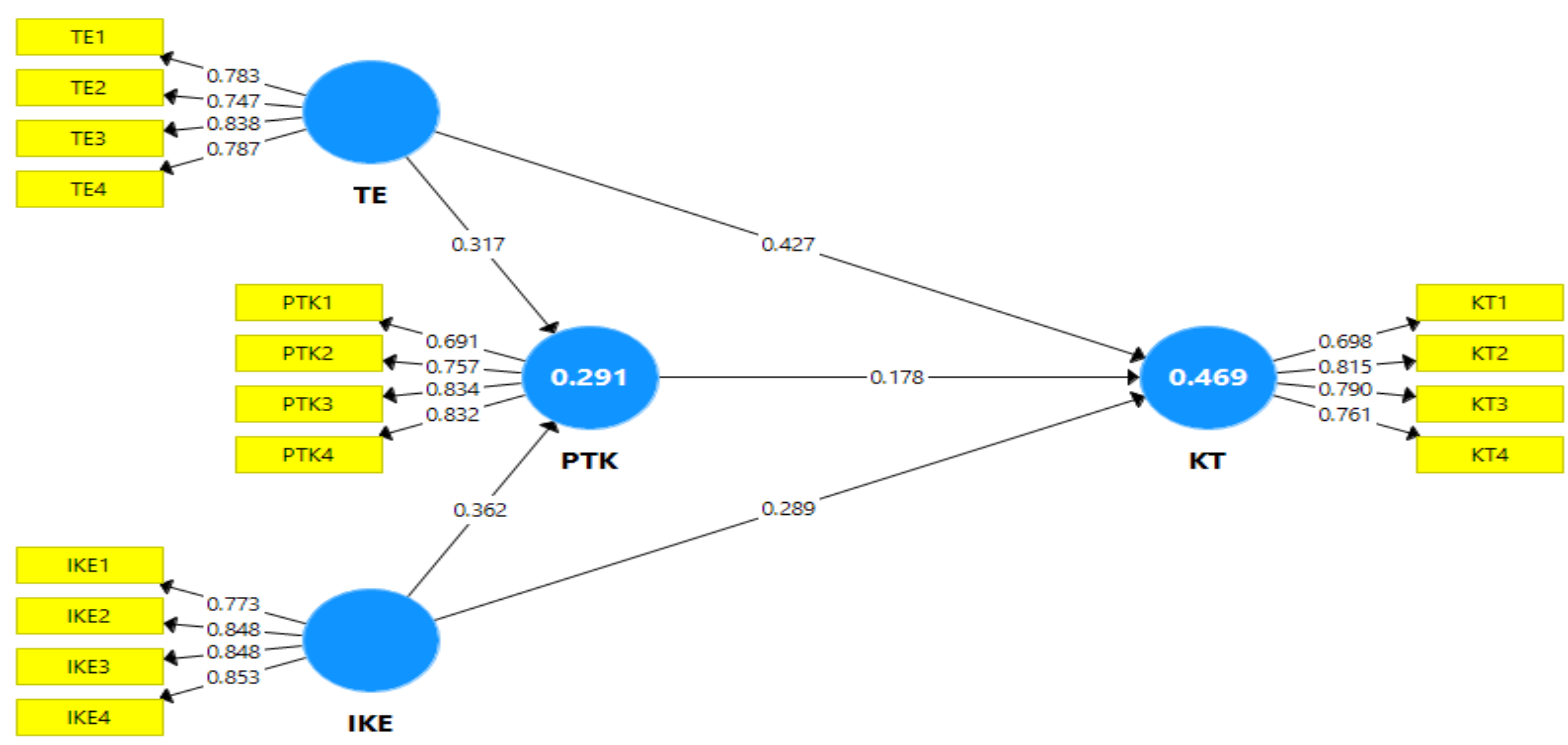

Gambar 2. Model Penelitian Valid 
Tabel 3. Items Loadings, Cronbach's Alpha, Composite Reliability, and Average Variance Extracted (AVE)

\begin{tabular}{|c|c|c|c|c|c|}
\hline Varables & Items & Loadings & $\begin{array}{l}\text { Cronbach's } \\
\text { Alpha }\end{array}$ & $\begin{array}{l}\text { Composite } \\
\text { Reliability }\end{array}$ & AVE \\
\hline \multirow[t]{4}{*}{ Team Efficacy (TE) } & TE1 & 0.783 & 0.798 & 0.868 & 0.623 \\
\hline & TE2 & 0.747 & & & \\
\hline & TE3 & 0.838 & & & \\
\hline & TE4 & 0.787 & & & \\
\hline \multirow{4}{*}{$\begin{array}{l}\text { Iklim Kecerdasan Emosional } \\
\text { (IKE) }\end{array}$} & IKE1 & 0.773 & 0.850 & 0.899 & 0.691 \\
\hline & IKE2 & 0.848 & & & \\
\hline & IKE3 & 0.848 & & & \\
\hline & IKE4 & 0.853 & & & \\
\hline \multirow{4}{*}{$\begin{array}{l}\text { Perencanaan Tim Kerja } \\
\text { (PTK) }\end{array}$} & PTK1 & 0.691 & 0.786 & 0.861 & 0.610 \\
\hline & PTK2 & 0.757 & & & \\
\hline & PTK3 & 0.834 & & & \\
\hline & PTK4 & 0.832 & & & \\
\hline \multirow[t]{4}{*}{ Kinerja Tim (KT) } & KT1 & 0.698 & 0.765 & 0.851 & 0.588 \\
\hline & KT2 & 0.815 & & & \\
\hline & KT3 & 0.790 & & & \\
\hline & KT4 & 0.761 & & & \\
\hline
\end{tabular}

Sumber: Data diolah dari output SmartPLS 3.0 (2021)

Tabel 4. Discriminant Validity

\begin{tabular}{lcccc}
\hline Variabel & IKE & KT & PTK & TE \\
\hline & & & & \\
Iklim Kecerdasan Emosional (IKE) & $\mathbf{0 . 8 3 1}$ & & & \\
Kinerja Tim (KT) & 0.478 & $\mathbf{0 . 7 6 7}$ & & \\
Perencanaan Tim Kerja (PTK) & 0.444 & 0.482 & $\mathbf{0 . 7 8 1}$ & \\
Team Efficacy (TE) & 0.259 & 0.575 & 0.411 & $\mathbf{0 . 7 8 9}$ \\
\hline Sumber: Data diola dai
\end{tabular}

Sumber: Data diolah dari output SmartPLS 3.0 (2021)

Tabel 5. Collinearity Statistics (VIF)

\begin{tabular}{lcccc}
\hline Variabel & IKE & KT & PTK & TE \\
\hline Iklim Kecerdasan Emosional (IKE) & & 1.256 & 1.072 & \\
Kinerja Tim (KT) & & 1.411 & & \\
Perencanaan Tim Kerja (PTK) & & 1.214 & 1.072 & \\
Team Efficacy (TE) & &
\end{tabular}

Sumber: Data diolah dari output SmartPLS 3.0 (2021)

Tabel 6. Nilai $R$ Square

\begin{tabular}{lcc}
\hline & R Square & R Square Adjusted \\
\hline Kinerja Tim (KT) & 0.469 & 0.466 \\
Perencanaan Tim Kerja (PTK) & 0.291 & 0.289 \\
\hline
\end{tabular}

Sumber: Data diolah dari output SmartPLS 3.0 (2021) 
Tabel 7. Hypotheses Testing

\begin{tabular}{llccccl}
\hline Hypotheses & Relationship & Beta & SE & T Statistics & P-Values & Decision \\
\hline H1 & TE -> PTK & 0.317 & 0.043 & 7.462 & 0.000 & Didukung \\
H2 & TE -> KT & 0.427 & 0.034 & 12.477 & 0.000 & Didukung \\
H3 & IKE -> PTK & 0.362 & 0.035 & 10.242 & 0.000 & Didukung \\
H4 & IKE -> KT & 0.289 & 0.037 & 7.834 & 0.000 & Didukung \\
H5 & PTK-> KT & 0.178 & 0.041 & 4.339 & 0.000 & Didukung \\
\hline
\end{tabular}

Sumber: Data diolah dari output SmartPLS 3.0 (2021)

Berdasarkan Tabel 6 di atas, nilai $R$ Square perencanaan tim kerja (PTK) sebesar 0.291 yang berarti bahwa variable perencanaan tim kerja (PTK) mampu dijelaskan oleh variabel team efficacy (TE) dan iklim kecerdasan emosional (IKE) sebesar 29.1\%, sedangkan sisanya sebesar 70.9\% dijelaskan oleh variabel lain yang tidak dibahas dalam penelitian ini. Nilai $R$ Square kinerja tim (KT) sebesar 0.469 yang berarti bahwa variabel kinerja tim (KT) mampu dijelaskan oleh variabel team efficacy (TE), iklim kecerdasan emosional (IKE), dan perencanaan tim kerja (PTK) sebesar 46.9\%, sedangkan sisanya sebesar $53.1 \%$ dijelaskan oleh variabel lain yang tidak dibahas dalam penelitian ini. Sedangkan Tabel 7 menampilkan $t$-statistics dan $p$-values yang menunjukkan pengaruh antar variable penelitian yang telah disebutkan. Kelima jalur yang dihipotesiskan dalam penelitian ini divalidasi dan didukung pada tingkat signifikansi 0.05. Perencanaan tim kerja dipengaruhi secara positif dan signifikan oleh team efficacy dan iklim kecerdasan emosional (H1 dan $\mathrm{H} 3$ didukung). Kinerja tim secara positif dan signifikan dipengaruhi oleh team efficacy, iklim kecerdasan emosional dan perencanaan tim kerja $(\mathrm{H} 2$, H4, dan H5 didukung).

\section{PEMBAHASAN}

Penelitian ini menyajikan aplikasi dan tes yang berguna dari teori kognitif sosial yang menyatakan bahwa karakteristik tim (yaitu, team efficacy) dan iklim tim (yaitu, iklim kecerdasan emosional) mendorong kinerja tim secara langsung dan tidak langsung melalui mediasi perencanaan tim kerja. Sedangkan efikasi telah dianggap sebagai penentu penting dari perilaku dan kinerja berdasarkan teori kognitif sosial, masuk akal juga bahwa, dalam kaitannya dengan perencanaan tim, iklim kecerdasan emosional (sebagaimana dikonfirmasi secara empiris oleh penelitian ini) ternyata juga signifikan sebagai prediktor untuk perencanaan tim kerja dan kinerja tim. Temuan ini masih jarang dibahas dalam literatur sebelumnya di Indonesia.

Berdasarkan literatur sebelumnya, keterkaitan yang kuat antara karakteristik masyarakat, iklim organisasi, pengaturan diri, dan kinerja yang telah ditetapkan di tingkat individu tampaknya juga ada di tingkat tim. Memperluas literatur, penelitian ini menyajikan bukti tentang bagaimana perencanaan tim kerja, memediasi efek karakteristik tim (yakni team efficacy) dan iklim tim (yakni: iklim kecerdasan emosional) terhadap kinerja tim. Penemuan semacam ini adalah hal baru yang sangat mungkin berkembang dan memiliki potensi luar biasa untuk penelitian di masa depan. Mediasi perencanaan tim kerja belum pernah dinilai sebelumnya dalam konteks industri manufaktur di Indonesia. Efek mediasi dari perencanaan tim kerja pada hubungan tidak langsung antara iklim kecerdasan emosional dan kinerja tim menyiratkan bahwa belajar memanfaatkan kecerdasan emosional selama interaksi interpersonal memfasilitasi komunikasi yang efektif untuk perencanaan tim. Team leaders perlu membimbing anggota tim untuk mengembangkan strategi pengaturan diri untuk meningkatkan kecerdasan emosional dan menciptakan konteks kerja sama yang mendorong penggunaan strategi ini. Hasilnya, anggota tim dapat menjadi terlatih untuk menyesuaikan peran penting dari perencanaan tim kerja dalam memperkuat kinerja tim.

Melalui perencanaan tim kerja seperti itu, anggota tim dapat dikoordinasikan dengan lebih baik untuk mencapai kinerja tim yang lebih baik. Pengaruh langsung tema efficacy dan iklim kecerdasan emosional pada kinerja tim mengungkapkan bahwa kedua faktor tersebut memiliki kekuatan berorientasi kinerja yang kuat. Oleh karena itu, tim yang dikelilingi oleh iklim tim yang baik cenderung 
menunjukkan performa lebih baik ketimbang tim serupa lainnya di iklim yang tidak kondusif. Iklim kerja tim yang baik membutuhkan waktu lama untuk berkembang, jadi manajemen organisasi (dalam hal ini perusahaan manufaktur) perlu merancang saluran komunikasi yang efisien untuk anggota tim dan mendapatkan konsensus mereka mengenai iklim kerja sama yang spesifik dan positif yang harus diupayakan oleh tim.

Ada tiga jalur model berbeda yang dapat memengaruhi kinerja tim. Pertama, team efficacy memengaruhi kinerja tim. Kedua, iklim kecerdasan emosional memengaruhi kinerja tim. Ketiga, perencanaan tim kerja memengaruhi kinerja tim. Temuan studi ini menunjukkan bahwa team efficacy adalah faktor paling kuat yang mendorong kinerja tim (0.427) dibandingkan dengan factor iklim kecerdasan emosional (0.289) dan perencanaan tim kerja (0.178). Oleh karena itu, penting bagi manajemen untuk memberikan perhatian lebih pada team efficacy. Kekuatan faktor-faktor ini membantu menjelaskan dengan baik masalah spesifik apa yang mungkin dihadapi anggota tim selama bergabung dalam tim.

\section{KESIMPULAN}

Kesimpulannya, penelitian ini menunjukkan bahwa fak xtor karakteristik tim (yang diwakili oleh team efficacy) dan faktor iklim tim (yang diwakili oleh iklim kecerdasan emosional) sangat memengaruhi perencanaan kerja tim dan kinerja tim. Demikian juga, perencanaan tim kerja memengaruhi secara positif dan signifikan terhadap kinerja tim. Studi ini menyakinkan bahwa teori SCT dapat diterapkan untuk memahami pembentukan kinerja tim, seperti juga menunjukkan pemahaman tentang perilaku dan kinerja individu. Studi ini juga memberikan validasi pelengkap dari teori SCT sebagai model kinerja tim dan menyarankan bahwa hal itu dapat digeneralisasikan di berbagai aktivitas tim pada organisasi lainnya.

Studi ini memiliki dua keterbatasan utama yang terkait dengan interpretasi temuan empiris. Pertama, karena penelitian ini menggunakan sampel karyawan manajerial sebuah industri manufaktur di Indonesia. Jadi, temuannya mungkin tidak secara tepat mencerminkan karakteristik dan persepsi beberapa tim di industri lain atau di negara lain atau pada budaya lain yang bisa jadi sangat berbeda sekali. Sifat terbatas dari sampel pada studi ini menyiratkan bahwa setiap generalisasi temuan dalam penelitian ini harus dilakukan dengan hati-hati. Kedua, mungkin ada faktor penentu eksogen penting lain dari kinerja tim di luar iklim tim, sebagaimana digunakan dalam dalam studi ini. Misalnya, model kepemimpinan (Goestjahjanti et al., 2020), readiness for change (Basuki et al., 2020; Novitasari, Sasono, et al., 2020b, 2020a; Zaman et al., 2020). Mengingat studi ini fokus teoritis pada SCT dan iklim tim, untuk penelitian di masa depan, penulis merekomendasikan untuk mengakomodasi lebih banyak prediktor dan membandingkan kemampuan penjelasan mereka dengan yang dinilai dalam penelitian ini. Penelitian berikutnya juga dapat mencoba untuk memperbaiki kekurangan studi ini dengan memasukkan lebih banyak variabel kontrol (misalnya, rasio perbedaan anggota dalam jenis kelamin, rasio perbedaan usia anggota, dan seterusnya), mensurvei lebih banyak anggota tim di berbagai industri dan budaya yang berbeda.

\section{SARAN}

1. Saran Praktis dalam penelitian ini yaitu dalam upaya mengelola dan meningkatkan secara berkesinambungan atas kinerja tim engineering, manajemen perusahaan perlu memperhatikan dua factor anteseden kinerja tim, yakni factor personal, yakni efficacy dengan memberikan dukungan dan kelonggaran untuk berkreasi dengan memperluas ruang otonomi kerja yang bertanggung jawab. Di samping itu, factor lingkungan perlu dijaga tetap kondusif, terutama iklim kecerdasan emosional. Iklim kerja jenis ini sangat tepat di era disrupsi yang penuh gejolak dan ketidakpastian, yang meningkatkan potensi dan risiko terpapar stress sangat tinggi, karena iklim kecerdasan emosional mampu menjadi bamper yang menambah kekuatan emosi dan daya juang untuk memenangkan persaingan di dunia usaha yang sarat dengan kompetisi.

2. Saran Teoritis terkait dengan Penelitian Selanjutnya dapat mencoba untuk memperbaiki kekurangan penelitian ini dengan memasukkan lebih banyak variabel control (misanya, Rasio Perbedaan anggota dalam jenis kelamin, Rasio Perbedaan Usia Anggota dan Seterusnya), Mensurvei lebih banyak Anggota Tim di berbagai industri dan budaya yang berbeda. 


\section{REFERENSI}

Agistiawati, E., Asbari, M., Basuki, S., Yuwono, T., \& Chidir, G. (2020). Exploring the Impact of Knowledge Sharing and Organizational Culture on Teacher Innovation Capability. International Journal of Science and Management Studies (IJSMS), 3(3), 62-77.

Akgün, A.E., Lynn, G.S., 2002. New product development team improvisation and speed-to-market: an extended model. Eur. J. Innov. Manag. 5, 117-129.

Alexander, S., Ruderman, M., 1987. The role of procedural and distributive justice in organizational behavior. Soc. Justice Res 1, 177-198.

Asbari, M. (2018). Ayah tanpa Wajah. Penerbit Tosca.

Asbari, M. (2019). Pengaruh Kepemimpinan Transformasional dan Iklim Organisasi terhadap Kinerja Dosen. Journal Of Communication Education, 13(2), 172-186.

Asbari, M. (2020). Is Transformational Leadership Suitable for Future Organizational Needs? International Journal of Sociology, Policy and Law (Ijospl), 1(01), 51-55.

Asbari, M., \& Novitasari, D. (2020a). Pengaruh Kesiapan untuk Berubah di Masa Pandemi Covid-19: Apa yang Dibutuhkan Pemimpin untuk Menjaga Kinerja. Jurnal Ekonomika: Manajemen, Akuntansi, Dan Perbankan Syari'ah, https://doi.org/https://doi.org/10.24903/je.v9i2.932

Asbari, M., \& Novitasari, D. (2020b). The Role of Readiness for Change on Part-Timer Employee Performance: Analysis of Transformational Leadership Practice in Convection Industry. Journal of Communication Education (JOCE), 14(02).

Asbari, M., \& Novitasari, D. (2021a). Pengaruh Aktivitas Berbagi Pengetahuan dan Mediasi Budaya terhadap Kemampuan Inovasi Guru. JMSP (Jurnal Manajemen Dan Supervisi Pendidikan), 5(1), 324-334.

Asbari, M., \& Novitasari, D. (2021b). Pengaruh Authentic Leadership terhadap Mentalitas Siap Berubah dan Kinerja Pegawai Paruh Waktu. Business Management Journal, 17(1), 73-88. https://doi.org/http://dx.doi.org/10.30813/bmj

Asbari, M., Novitasari, D., Gazali, G., Silitonga, N., \& Pebrina, E. T. (2020). Analisis Kesiapan untuk Berubah di Masa Pandemi Covid-19: Studi Pengaruh Kepemimpinan Transformasional terhadap Kinerja Karyawan. Jurnal Perspektif, 18(2), 147-159. https://ejournal.bsi.ac.id/ejurnal/index.php/perspektif/article/view/8576

Asbari, M., Novitasari, D., Pebrina, E. T., \& Santoso, J. (2020). Work-Family Conflict and Employee Performance during Covid-19 Pandemic: What is the Role of Mental Readiness to Change? JPBM (Jurnal Pendidikan Bisnis Dan Manajemen), 6(2).

Asbari, M., Novitasari, D., Silitonga, N., Sutardi, D., \& Gazali. (2020). Analisis Readiness for Change terhadap Kinerja: Perspektif Karyawan Kontrak di Masa Pandemi Covid-19. JEMASI: Jurnal Ekonomi Manajemen Dan Akuntansi, 16(2), 1-16. https://doi.org/https://doi.org/10.35449/jemasi.v16i2.153

Asbari, M., Purba, J. T., Hariandja, E. S., \& Sudibjo, N. (2021). From Leadership to Innovation: Managing Employee Creativity. Jurnal Manajemen Strategi Dan Aplikasi Bisnis, 4(1), 143-154.

Asbari, M., Santoso, P. B., \& Prasetya, A. B. (2020). Elitical And Antidemocratic Transformational Leadership Critics: Is It Still Relevant? (A Literature Study). INTERNATIONAL JOURNAL OF SOCIAL, POLICY AND LAW, 1(1), 12-16.

Ayoko, O.B., Callan, V.J., Härtel, C.E., 2008. The influence of team emotional intelligence climate on conflict and team members' reactions to conflict. Small Group Res. 39, 121-149.

Bandura, A., 1986. Social Foundations of Thought and Action. Prentice Hall, Englewood Cliffs, NJ.

Bandura, A., 2001. Social cognitive theory of mass communication. Media Psychol. 3, 265-299. 
Basuki, S., Novitasari, D., Fahlevi, M., Nadeak, M., Fahmi, K., Pebrina, E. T., Sudiyono, R. N., \& Asbari, M. (2020). Performance Analysis of Female Employees in the Covid-19 Pandemic Period: The Effects of Readiness for Change and Effectiveness of Transformational Leadership. Solid State Technology, 63(1s), 201-217.

Brown, A.L., Bransford, J.D., Ferrara, R.A., Campione, J.C., 1983. Learning, remembering, and understanding. In: Flavell, J.H., Markman, E.M. (Eds.), Handbook of Child Psychology. Wiley, New York, pp. 77-166.

Chen, C.H., Ho, Y.H., Chan, L.J., 2010. Team implicit coordination in manufactory industry: assessing the mediating role of empowering leadership and team efficacy. 2010 International Symposium on Computer Communication Control and Automation (3CA), pp. 459-462.

Chin, W. (1998). The Partial Least Squares Approach to Structural Equation Modeling (E. Modern Methods for Business Research, In: G. A. Marcoulides (ed.)). Lawrence Erlbaum Associates Publisher.

Côté, S., Miners, C.T.H., 2006. Emotional intelligence, cognitive intelligence, and job performance. Adm. Sci. Q. 51, 1-28.

Creswell, J. W., \& Creswell, J. D. (2017). Research design: Qualitative, quantitative, and mixed methods approaches. Sage publications.

DeShon, R.P., Gillespie, J.Z., 2005. A motivated action theory account of goal orientation. J. Appl. Psychol. 90, 1096-1127.

Ford, J.K., Smith, E.M., Weissbein, D.A., Gully, S.M., Salas, E., 1998. Relationships of goal orientation, metacognitive activity, and practice strategies with learning outcomes and transfer. J. Appl. Psychol. 83, 218-233.

Fornell, C., \& Larcker, D. F. (1981). Evaluating Structural Equation Models with Unobservable Variables and Measurement Error. Journal of Marketing Research, 18(1), 39. https://doi.org/10.2307/3151312

Gazali, G., Asbari, M., \& Novitasari, D. (2020). Peran Readiness for Change Mentality terhadap Kinerja Pegawai Kontrak Industri Alas Kaki. Widya Cipta: Jurnal Sekretari Dan Manajemen, 4(2), 169-182. https://doi.org/10.31294/widyacipta.v4i2.8823

Ghozali, I. (2014). Structural Equation Modeling, Metode Alternatif dengan Partial Least Square (PLS) (4th ed.). Badan Penerbit Universitas Diponegoro.

Goestjahjanti, S. F., Novitasari, D., Hutagalung, D., Asbari, M., \& Supono, J. (2020). Impact of Talent Management, Authentic Leadership and Employee Engagement on Job Satisfaction: Evidence From South East Asian Industries. Journal of Critical Reviews, 7(19), 67-88.

Gully, S.M., Incalcaterra, K.A., Joshi, A., Beaubien, J.M., 2002. A meta-analysis of team-efficacy, potency, and performance: interdependence and level of analysis as moderators of observed relationships. J. Appl. Psychol. 87, 819-832.

Hair Jr, J. F., Sarstedt, M., Ringle, C. M., \& Gudergan, S. P. (2017). Advanced issues in partial least squares structural equation modeling. saGe publications.

Hair, J. F., Black, W. C., Babin, B. J., \& Anderson, R. E. (2010). Multivariate Data Analysis (7th ed.). Pearson Prentice Hall.

Hair, J. F., Hult, G. T., Ringle, C. M., \& Sarstedt, M. (2014). A primer partial least squaresstructural equation modeling (PLS-SEM). SAGE Publications.

Hair, Joe F, Sarstedt, M., Ringle, C. M., \& Mena, J. A. (2012). An assessment of the use of partial least squares structural equation modeling in marketing research. Journal of the Academy of Marketing Science, 40(3), 414-433.

Holton, J.A., 2001. Building trust and collaboration in a virtual team. Team Perform. Manag. 7, 36-47. 
Hooper, D.T., Martin, R., 2005. The impact of LMX differentiation on perceptions of team conflict and procedural justice climate. In: Myors, B. (Ed.), 6th Australian Industrial and Organisational Psychology Conference, Surfers Paradise Marriott Resort, Gold Coast, QLD, p. 131.

Hung, R. Y.-Y., Lien, B. Y.-H., Fang, S.-C., \& McLean, G. N. (2010). Knowledge as a facilitator for enhancing innovation performance through total quality management. Total Quality Management, 21(4), 425-438.

Hutagalung, D., Asbari, M., Fayzhall, M., Ariyanto, E., Agistiawati, E., Sudiyono, R. N., Waruwu, H., Goestjahjanti, F. S., Winanti, W., \& Yuwono, T. (2020). Peran Religiusitas, Kepemimpinan Transformasional, Kepuasan Kerja dan Mediasi Organizational Citizenship Behavior terhadap Kinerja Guru. EduPsyCouns: Journal of Education, Psychology and Counseling, 2(1), 311-326.

Janicik, G.A., Bartel, C.A., 2003. Talking about time: effects of temporal planning and time awareness norms on group coordination and performance. Group Dyn. Theory Res. Pract. 7, 122-134.

Joe, S.W., Lin, C.P., 2008. Learning online community citizenship behavior: a socio-cognitive model. Cyberpsychol. Behav. 11, 367-370.

Jordan, P.J., Troth, A.C., 2004. Managing emotions during team problem solving. Hum. Perform. 17, 195-218.

Jumiran, Novitasari, D., Nugroho, Y. A., Sutardi, D., Sasono, I., \& Asbari, M. (2020). Pengaruh Dimensi Kepemimpinan Transformasional terhadap Kepuasan Kerja dan Komitmen Organisasional: Studi Kasus pada Dosen Perguruan Tinggi Swasta. EduPsyCouns: Journal of Education, Psychology and Counseling, 2(1), 600-621.

Kamar, K., Novitasari, D., Asbari, M., Winanti, W., \& Goestjahjanti, F. S. (2020). Enhancing Employee Performance During the Covid-19 Pandemic: the Role of Readiness for Change Mentality. JDM (Jurnal Dinamika Manajemen), 11(2), 154-166.

Law, K.S., Wong, C.S., Song, L.J., 2004. The construct and criterion validity of emotional intelligence and its potential utility for management studies. J. Appl. Psychol. 89, 483-496.

Lin, C., Peng, T., 2010. From organizational citizenship behaviour to team performance: the mediation of group cohesion and collective efficacy. Manag. Organ. Rev. 6, 55-75.

Lind, E.A., Tyler, T.R., 1988. The Social Psychology of Procedural Justice. Plenum, New York.

lukayode, A.A., Ehigie, B.O., 2005. Psychological diversity and team interaction processes: a study of oil-drilling work teams in Nigeria. Team Perform. Manag. 11, 280-301.

Maesaroh, S., Asbari, M., Hutagalung, D., Mustofa, M., Agistiawati, E., Basuki, S., Radita, F. R., Nurasiah, N., Yulia, Y., \& Singgih, E. (2020). Pengaruh Religiusitas dan Kepemimpinan Transformasional terhadap Kinerja Guru melalui Mediasi Organizational Citizenship Behavior. EduPsyCouns: Journal of Education, Psychology and Counseling, 2(1), 276-290.

Mehta, A., Field, H., Armenakis, A., Mehta, N., 2009. Team goal orientation and team performance: the mediating role of team planning. J. Manag. 35, 1026-1046.

Moorman, R.H., 1991. Relationship between organizational justice and organizational citizenship behaviors: do fairness perceptions influence employee citizenship? J. Appl. Psychol. 76, 845855.

Mosley Jr., D.C., Boyar, S.L., Carson, C.M., Pearson, A.W., 2008. A production self-efficacy scale: an exploratory study. J. Manag. Issues 20, 272-285.

Naumann, S.E., Bennett, N., 2002. The effects of procedural justice climate on work group performance. Small Group Res. 33, 361-378.

Novitasari, D., \& Asbari, M. (2020a). Pengaruh Kepemimpinan Transformasional terhadap Kinerja Karyawan: Peran Kesiapan untuk Berubah sebagai Mediator. Jurnal Manajemen, 10(2), 84-99. 
Novitasari, D., \& Asbari, M. (2020b). Urgensi Kepemimpinan dan Mentalitas Siap Berubah Terhadap Kinerja Pegawai di Musim Pandemi Covid-19. Jurnal REKOMEN (Riset Ekonomi Manajemen), 4(1), 66-80.

Novitasari, D., Asbari, M., Sutardi, D., Gazali, G., \& Silitonga, N. (2020). Pengaruh Kesiapan untuk Berubah dan Efektivitas Kepemimpinan Transformasional terhadap Kinerja Karyawan di Masa Pandemi Covid-19. Value: Jurnal Manajemen Dan Akuntansi, 15(2), 22-37.

Novitasari, D., Asbari, M., Wijayanti, L. M., Hyun, C. C., \& Farhan, M. (2020). The Role of Religiosity, Leadership Style, Job Satisfaction and Organizational Citizenship Behavior Mediation on Woman Teachers' Performance. Solid State Technology, 63(6), 2953-2967. http://solidstatetechnology.us/index.php/JSST/article/view/3380

Novitasari, D., Goestjahjanti, F. S., \& Asbari, M. (2020). The Role of Readiness to Change between Transformational Leadership and Performance: Evidence from a Hospital during Covid-19 Pandemic. APMBA (Asia Pacific Management and Business Application), 9(1), 37-56. https://doi.org/10.21776/ub.apmba.2020.009.01.4

Novitasari, D., Sasono, I., \& Asbari, M. (2020a). Work-Family Conflict and Worker's Performance during Covid-19 Pandemic: What is the Role of Readiness to Change Mentality? International Journal of Science and Management Studies (IJSMS), 3(4), 122-134.

Novitasari, D., Sasono, I., \& Asbari, M. (2020b). Work-Family Conflict and Worker's Performance during Covid-19 Pandemic: What is the Role of Readiness to Change Mentality? International Journal of Science and Management Studies (IJSMS), 3(4), 122-134. http://www.ijsmsjournal.org/volume3-issue4.html

Novitasari, D., Yuwono, T., Cahyono, Y., Asbari, M., \& Sajudin, M. (2020). Effect of Hard Skills, Soft Skills, Organizational Learning and Innovation Capability on Indonesian Teachers' Performance during Covid-19 Pandemic. Solid State Technology, 63(6), 2927-2952. http://www.solidstatetechnology.us/index.php/JSST/article/view/3379

Nuryanti, Y., Novitasari, D., Nugroho, Y. A., Fauji, A., Gazali, \& Asbari, M. (2020). Meningkatkan Komitmen Organisasional Dosen: Analisis Pengaruh Kepemimpinan Perguruan Tinggi dan Kepuasan Intrinsik \& Ekstrinsik Dosen. EduPsyCouns: Journal of Education, Psychology and Counseling, 2(1), 561-581.

O'Leary, M.B., Mortensen, M., 2010. Go (con)figure: subgroups, imbalance, and isolates in geographically dispersed teams. Organ. Sci. 21, 115-131.

Pajares, F., 1997. Current directions in self-efficacy research. In: Maehr, M.L., Pintrich, P.R. (Eds.), Advances in Motivation and Achievement. JAI Press, Greenwich, CT, pp. 1-49.

Perlini, A.H., Halverson, T.R., 2006. Emotional intelligence in the National Hockey League. Can. J. Behav. Sci. 38, 109-120.

Prussia, G.E., Kinicki, A.J., 1996. A motivational investigation of group effectiveness using social cognitive theory. J. Appl. Psychol. 81, 187-198.

Renn, R.W., 1998. Participation's effect on task performance, mediating roles of goal acceptance and procedural justice. J. Bus. Res. 41, 115-125.

Richter, A.W., Scully, J., West, M.A., 2005. Intergroup conflict and intergroup effectiveness in organizations: theory and scale development. Eur. J. Work. Organ. Psychol. 14, 177-203.

Robins, S., 2002. A consultant's guide to understanding and promoting emotional intelligence in the workplace. In: Lowman, R. (Ed.), Handbook of Organizational Consulting Psychology. John Wiley \& Sons Inc., New York, N.Y.

Roscoe, J. T. (1975). Fundamental research statistics for the behavioral sciences [by] John T. Roscoe.

Salovey, P., Mayer, J.M., 1990. Emotional Intelligence: Imagination, Cognition, and Personality. Harper \& Row, N.Y. 
Sarstedt, M., Ringle, C. M., Smith, D., Reams, R., \& Hair Jr, J. F. (2014). Partial least squares structural equation modeling (PLS-SEM): A useful tool for family business researchers. Journal of Family Business Strategy, 5(1), 105-115.

Sekaran, U., \& Bougie, R. (2016). Research methods for business: A skill building approach. John Wiley \& Sons.

Silitonga, N., Novitasari, D., Sutardi, D., Sopa, A., Asbari, M., Yulia, Y., Supono, J., \& Fauji, A. (2020). The Relationship of Transformational Leadership, Organizational Justice and Organizational Commitment: a Mediation Effect of Job Satisfaction. Journal of Critical Reviews, 7(19), 89-108.

Sudiyono, R. N., Goestjahjanti, F. S., Asbari, M., Agistiawati, E., Fayzhall, M., Yani, A., Winanti, W., Yuwono, T., Nurasiah, N., \& Yulia, Y. (2020). Meningkatkan Komitmen dan Kinerja Dosen: Apa Peran Manajemen Perguruan Tinggi? EduPsyCouns: Journal of Education, Psychology and Counseling, 2(1), 337-352.

Suprapti, S., Asbari, M., Cahyono, Y., \& Mufid, A. (2020). Leadership Style, Organizational Culture and Innovative Behavior on Public Health Center Performance during Pandemic Covid-19. Journal of Industrial Engineering \& Management Research, 1(2), 76-88.

Sutardi, D., Novitasari, D., Asbari, M., Silitonga, N., Nugroho, Y. A., Hutagalung, D., Mustofa, Chidir, G., Basuki, S., \& Yuwono, T. (2020). Pengaruh Work-Family Conflict, Stres Kerja dan Social Support terhadap Kepuasan Kerja: Studi Kasus pada Guru Wanita di Tangerang. EduPsyCouns: Journal of Education, Psychology and Counseling, 2(1), 482-498.

Sy, T., Tram, S., O'Hara, L.A., 2006. Relation of employee and manager emotional intelligence to job satisfaction and performance. J. Vocat. Behav. 68, 461-473.

Tremblay, M., Cloutier, J., Simard, G., Chenevert, D., Vandenberghe, C., 2010. The role of HRM practices, procedural justice, organizational support and trust in organizational commitment and in-role and extra-role performance. Int. J. Hum. Resour. Manag. 21, 405-433.

Tsai, Y.H., Lin, C.P., Chiu, C.K., Joe, S.W., 2009. Understanding learning behavior using location and prior performance as moderators. Soc. Sci. J. 46, 787-799.

van Emmerik, H., Jawahar, I.M., Schreurs, B., de Cuyper, N., 2011. Social capital, team efficacy and team potency: the mediating role of team learning behaviors. Career Dev. Int. 16, 82-99.

van Kleef, G.A., Homan, A.C., Beersma, B., van Knippenberg, D., van Knippenberg, B., Damen, F., 2009. Searing sentiment or cold calculation? The effects of leader emotional displays on team performance depend on follower epistemic motivation. Acad. Manag. J. 52, 562-580.

Weingart, L.R., 1992. Impact of group goals, task component complexity, effort, and planning on group performance. J. Appl. Psychol. 77, 682-693.

Weldon, E., Jehn, K.A., Pradhan, P., 1991. Processes that mediate the relationship between group goals and improved group performance. J. Pers. Soc. Psychol. 61, 555-569.

Yang, J., Mossholder, K.W., Peng, T.K., 2007. Procedural justice climate and group power distance: an examination of cross-level interaction effects. J. Appl. Psychol. 92, 681-692.

Yoon, J., 1996. Fairness issues and job satisfaction among Korean employees: the significance of status value and procedural justice in work orientation. Soc. Justice Res 9, 121-143.

Yuwono, T., Wiyono, N., Asbari, M., Novitasari, D., \& Silitonga, N. (2020). Analisis Pengaruh Efektivitas Kepemimpinan Transformasional dan Kesiapan untuk Berubah terhadap Kinerja Karyawan Wanita di Masa Pandemi Covid-19. Jurnal Ilmiah Mahasiswa Ekonomi Manajemen, 5(3), 615-632.

Zaman, M. N., Novitasari, D., Goestjahjanti, F. S., Fahlevi, M., Nadeak, M., Fahmi, K., Setiawan, T., \& Asbari, M. (2020). Effect of Readiness to Change and Effectiveness of Transformational Leadership on Workers' Performance during Covid-19 Pandemic. Solid State Technology, 63(1s), 185-200. http://www.solidstatetechnology.us/index.php/JSST/article/view/708 
Zimmerman, B.J., 2001. Attaining self-regulation. In: Boekaerts, M., Pintrich, P.R., Zeidner, M. (Eds.), Handbook of Self-Regulation. Academic Press, San Diego, CA, pp. 13-35. 